\title{
An Aristotelian at the Academy: Simone Porzio and the Problem of Philosophical Vulgarisation
}

\author{
Eva Del Soldato
}

Philosophy and the vernacular were not irreconcilable even during the Middle Ages and Early Renaissance: in addition to the 'élite popularization' of encyclopaedic works, and the vulgarisation of short treatises that often served as a form of exercise for translators, which became common in Europe from the thirteenth century onward, ${ }^{1}$ the rebirth of Platonism in late fifteenth century was accompanied by the diffusion of vernacular texts related to it. ${ }^{2}$ On the margins of the official curriculum studiorum, Renaissance Neoplatonism was not bound to formal schemes and often directed to a wider audience, one that did not necessarily practice philosophy in a specialized form: it encountered tremendous success in courts and humanistic circles thanks to the agreeability of its subjects (love, soul, etc.) and its style.

Instead, the vernacular was substantially neglected where philosophy was traditionally and professionally practiced, viz. at the universities, which continued to focus on an established Latin speaking Aristotelianism. In spite of (rare) patrons like Charles v of France, who, in the second half of the fourteenth century commissioned a series of vernacular translations of Aristotelian works (including Politics, Ethics, On the Heavens and the apocryphal Economics) from the professor Nicole Oresme, Aristotle's ideas had by and large remained

1 See Sturlese, 'Filosofia in volgare', pp. 2-3; I derive the expression 'elitarian popularisation' from Crisciani, 'Michele Savonarola', p. 448.

2 For the Neoplatonic appreciation of vernacular between the fifteenth and sixteenth centuries, they are significant the cases of Marsilio Ficino and his pupil Francesco Cattani da Diacceto, who both vernacularized by themselves some of their treatises, originally in Latin: see, e.g., Ficino, El libro dell'amore, but also the assessment by Varchi, Vita di Francesco Cattani da Diacceto, pp. 14-15. See also Buck, Der Einfluss des Platonismus auf die volkssprachliche Literatur im Florentiner Quattrocento, 1965. Plato's dialogues translated in vernacular had a rich printed circulation around 1540s, in particular in Italy and in France, see Schmidt, 'Traducteurs français de Platon'; E. Garin, Storia della filosofia italiana, 2, p. 611. But also cf. for other considerations J. Hankins, Plato in the Italian Renaissance, 2, pp. 738-96. 
locked in the fortress of the university and its lingua franca for centuries. ${ }^{3}$ The rigid structure of Aristotelian philosophy, consolidated by medieval scholasticism, was a serious obstacle to a vernacular translation: devoid of the kind of stylistic appeal that humanists valued, weighed down by too many technical expressions, Aristotelian writings were in general only accessible to those who possessed a specialized philosophical background and, correspondingly, knew Latin. There also existed a degree of professional jealousy, the desire of professors to keep the highest theoretical questions away from a popular consumption. ${ }^{4}$

However, in the sixteenth century, it was precisely Aristotelianism which made an important theoretical contribution to an elevated use of the vernacular. The celebrated Mantuan magister Pietro Pomponazzi-who died in 1525-spoke the following words as a character in the Dialogo delle lingue, written around 1542 by a pupil of his, Sperone Speroni:

Più tosto vo' credere ad Aristotile e alla verità, che lingua alcuna del mondo (sia qual si voglia) non possa aver da sé stessa privilegio di significare i concetti del nostro animo, ma tutto consista nello arbitrio delle persone. Onde chi vorrà parlar di filosofia con parole mantovane $o$ milanesi, non gli può esser disdetto a ragione, più che disdetto gli sia il filosofare e l'intender la cagion delle cose. Vero è che, perché il mondo

3 Other exceptions are often related to less technical works, and connected to the commission of a noble man: in France, the Meteorology by Mahieu le Vilain (ca. 1275), the lost Politics by Pierre de Paris (ca. 1300) and the later Problemata by Évrart de Conty (ca. 1380). Different examples are the German Categories and On interpretation by Notker (1oth century) and the Meteorology by an anonym Florentine (14th century). In the 14th century, multiple versions of the Ethics and Rhetoric were made, too. I also remember the vernacularisation of pseudo-Aristotelian works, alien to the university's curricula, such as the successful Secretum Secretorum. See, among others, Caroti, 'Nicole Oresme: dalla "quaestio" alle "glose"'; Grant, 'Nicole Oresme, Aristotle's On the Heavens, and the Court of Charles v'; Librandi, La «Metaura» d'Aristotile; Lusignan, 'Nicole Oresme traducteur'; Williams, 'The Vernacular Tradition of the Pseudo-Aristotelian Secrets of Secrets'. On the case of the Bolognese professor of medicine Taddeo Alderotti (13th c.) as translator of the Ethics, see Gentili, L'uomo aristotelico alle origini della letteratura italiana. A list of Aristotelian Italian vernacularizations is now available on the database of the 'Vernacular Aristotelianism in Renaissance Italy' project led by D.A. Lines: http://www.2.warwick.ac.uk/fac/arts/ren/projects/vernaculararistotelianism/ database/. See also Bianchi, 'Per una storia dell'aristotelismo "volgare” nel Rinascimento'.

4 See Bianchi, 'Il core di filosofare volgarmente', pp. 499-500, who cites two attestations of elitist hostility against philosophy in vernacular: the LXXviII novella of the Novellino (13th c.) and a passage from Speroni, 'Dialogo delle lingue', pp. 627-28. 
non ha in costume di parlar di filosofia se non greco o latino, già crediamo che far non possa altramente; e quindi viene che solamente di cose vili e volgari volgarmente parla e scrive la nostra età.

I prefer to believe in Aristotle and in the truth, that there is no language in the world - any language at all — which possesses the exclusive privilege of understanding the concepts of our soul, rather that everything consists in human will. Therefore, those who would desire to speak about philosophy with Mantuan or Milanese words cannot be prevented from doing so, in the same way that they cannot be prevented from practicing philosophy and understanding the causes of things. But, since the world is accustomed to speak about philosophy only in Greek and in Latin, we believe we cannot do so in any other way; and so it happens that our Age speaks and writes in the volgare only about vulgar and poor subjects. ${ }^{5}$

All languages are of equal value, even local and vernacular languages like Mantovano and Milanese, and this is because they are all created by an act of human spirit: therefore thought-conceived in its higher philosophical sense-cannot be limited to a single linguistic form. We do not know if Pomponazzi ever actually pronounced this passionate speech in defence of a philosophical use of volgare, but the words that Speroni put in his mouth were genuinely Aristotelian: the conventionality in naming things-no name is a name by nature, but $\varkappa \alpha \tau \dot{\alpha} \sigma v v \theta \dot{\eta} \kappa \eta v$, as stated in On Interpretation, 16a27-30-that is the immutability of objects in a world of mutable words, and the consequent prevalence of res over verba, were all principles which led to a legitimization of a universal practice of translation. ${ }^{6}$

Speroni's dialogue was a product of the Accademia degli Infiammati, one of the new literary academies that arose in Italy during the fourth and the fifth decades of the sixteenth century to promote the vernacular as a language of

5 Speroni, 'Dialogo delle lingue', p. 625 (translation is mine). The real Pomponazzi never wrote in vernacular, but he used to insert sections in volgare in his lessons and he never achieved a full mastery of Latin even in his written works, in which the Latin is clearly derived from vernacular models. See the texts published in Nardi, Studi su Pietro Pomponazzi, and I. Paccagnella, 'La lingua del Peretto'.

6 See Garin, 'Discussioni sulla retorica'; C. Vasoli, Su alcuni problemi e discussioni logiche del Cinquecento italiano. A similar point of view has been already expressed by the Platonist Francesco Cattani da Diacceto. See Del Soldato, 'The Elitist Vernacular of Francesco Cattani da Diacceto and its Afterlife'. 
elevated discourse. ${ }^{7}$ The Infiammati flourished in Padua, where the university was a traditional peripatetic stronghold and therefore many of the Academy's members possessed an Aristotelian background. The Infiammati focused on the project of establishing a noble vernacular, founded on Bembo's teachings and capable of being used in any literary genre. Philosophy was included and many people who also attended the university made important contributions to their program. Among these was Benedetto Varchi, who offered popularized Aristotelian lessons in the vernacular at the Accademia, and also began to translate and compose vernacular commentaries on Aristotle's Organon and Ethics. ${ }^{8}$ If Varchi's versions remained fragmentary, unfinished and never printed, the vernacular Aristotle of Alessandro Piccolomini met with greater success: this Sienese nobleman translated and published the Rhetoric and Poetics, and offered not a literal version, but a kind of commentary of other works, most notably of the Physics in La filosofia naturale, a text in which he announced a concrete and self-conscious project to compose philosophical treatises in the vernacular. After having suggested that the ancient Hellenic philosophers wrote their works in Greek in order to glorify their country, he claimed:

Non so per qual mala fortuna nostra, tra tanti escelentisismi Filosofi, che haviam'hoggi, non sia stato per ancora alcuno, che de le cose di Filosofia $[\ldots]$ habbia scritto nella lingua nostra, si come in essa non son mancati molti che Tragedie, Comedie, Satire, Sonetti, Stanze, Canzoni, Historie et Novelle hanno scritto vaghissimamente e dottamente.

I do not know for what unfortunate reason, although we have today many excellent philosophers, not one of them has yet written about philosophy in our language, whereas we have many authors who have written very nicely and very eruditely tragedies, comedies, satires, sonnets, stanzas, songs, histories and tales. ${ }^{9}$

In any case this complaint did not come from someone deeply involved in the university milieu: Piccolomini occupied a chair—of Filosofia morale, a

7 F. Bruni, 'Sperone Speroni e l'Accademia degli Infiammati'; Vasoli, 'Sperone Speroni: La filosofia e la lingua'.

8 Varchi, L'Hercolano, p. 139; and see Samuels, 'Benedetto Varchi'; Siekiera, 'Leredità del Varchi'. Varchi also commented the first book of the Meteorology. Simon Gilson is preparing a study on this topic.

9 Piccolomini, Parte prima della Filosofia naturale, A3r-4r (translation is mine). See also Caroti, 'L' "Aristotele italiano" di Alessandro Piccolomini'. 
less technical subject - at the university of Siena only for one year, between 1545 and $1546 .^{10}$ Similarly, Pomponazzi's pupil Sperone Speroni taught logic and philosophy for a short period, before becoming involved in the Academy.11 Another Infiammato, Bernardino Tomitano, who wrote the Ragionamenti della lingua toscana (1545), a volgare treatise in the form of a dialogue on rhetoric and poetics, was a professor of logic, but in any case never employed the vernacular for his professional works of philosophy, in print or in manuscript. ${ }^{22}$ Finally, as mentioned above, Varchi taught Aristotle only in an academy context, and the attempt of the Infiammati to establish a synergy capable of attracting students from the University of Padua had the paradoxical outcome of forcing Varchi to lecture in Latin, rather than in the vernacular, in order to allow the foreigners to understand him. ${ }^{13}$ And if this was the situation of the Accademia degli Infiammati, it cannot be forgotten that many other Aristotelian worksboth translations and original texts-such as those of Brucioli, Segni and Florimonte, were created at the same time. Though some of these works were probably addressed to students who were willing to read the Philosopher in a more accessible form, these products all emerged outside the universities. ${ }^{14}$

However, it is not possible to conclude that sixteenth century professors from the faculties of Arts were completely indifferent, or even hostile, to the use of the vernacular for philosophical debates: the case of Simone Porzio, the most popular Aristotelian magister of that period, who at the same time was a member of an important academy, the Accademia Fiorentina, demonstrates that there was not a complete separation between the universities and

10 His career subsequently continued in the Church and he became archbishop of Patrai, see Cerreta, Alessandro Piccolomini, pp. 54-6. On the status of Ethics in Renaissance Universities, cf. Lines, Aristotle's 'Ethics', p. 384.

11 And in any case his attitude towards philosophy in vernacular became ambiguous according to Mikkeli, 'The Cultural Programmes of Alessandro Piccolomini and Sperone Speroni'. A different point of view is expressed by Bianchi, 'Volgarizzare Aristotle. Per chi?'. He taught logic in Padua until 1563, when he tried without success to obtain the more prestigious chair of 'filosofia ordinaria'; then he left the university and he practiced as a physician until his death in 1576 (see Davi, Bernardino Tomitano filosofo, medico $e$ letterato (1517-1576); Pecoraro, 'Tomitano, Bernardino'). On Aristotle in the Ragionamenti see Girardi, Il sapere e le lettere in Bernardino Tomitano.

13 See Lo Re, Politica e cultura nella Firenze cosimiana: Studi su Benedetto Varchi.

14 See Bianchi, 'From Jacques Léfebvre d'Étaples to Giulio Landi'; Del Soldato, '"Le migliori opere di Aristotele”: Antonio Brucioli as a Translator of Philosophy'; Lines, 'Rethinking Renaissance Aristotelianism: Bernardo Segni's Ethica, the Florentine Academy and the Vernacular'. 
the Academies devoted to the valorisation of the vernacular, even if their relationship was subtle and complex. ${ }^{15}$

Porzio was born in Naples in 1496 or 1497. During his entire life he enjoyed extraordinary success and fame: he taught in Naples, where he earned the esteem of the Viceroy Pedro de Toledo, who made Porzio his personal physician. But by the end of 1530 s, cultural life in Naples began to evaporate under the weight of the censorship applied by don Pedro in order to prevent political and religious subversion: during these very years, the Spanish evangelical Juan de Valdés had gathered a wide following in the city's intellectual circles. ${ }^{16}$ Porzio, not completely alien to this evangelical ferment, and in any case desirous of abandoning what he described as a "Neapolitan purgatory", took the opportunity for a bold flight, and accepted an incredibly well-paid position as professore sopraordinario at the university of Pisa, where he had studied during his Bildungsjahre under the guidance of Agostino Nifo. ${ }^{17}$ Duke Cosimo de' Medici was eager to appoint Porzio at his University, and he dared to challenge the anger of his father-in-law Pedro de Toledo in order to procure his service. Don Pedro never forgave Porzio for his 'betrayal', but the philosopher nevertheless managed to enjoy a very happy and productive period in Tuscany.

From 1545 to $155^{2}$ Porzio represented the greatest attraction at the university, earning for himself no less than the title of 'Prince of philosophers'. ${ }^{18}$ And his position was made even stronger by the special favour he received from Duke Cosimo: at ease not only inside the university aulae, but also in more worldly circles, Porzio wasted no time in joining the cultural institution that Cosimo was promoting during those years, the Accademia Fiorentina.

Born a few years earlier under the name of the Accademia degli Umidi, this group had a linguistic program which clashed, even in its choice of name, with the Paduan Infiammati: its members were interested in a valorisation of vernacular literature as well, but they modelled their ideal not on a literary model, but rather on spoken Florentine. ${ }^{19}$ After taking power in 1537, Cosimo selected the Umidi as an ideal group to provide a cultural foundation for his leadership

\footnotetext{
15 On Porzio see: Fiorentino, 'Simone Porzio'; Saitta, 'Laristotelico Simone Porzio'; Vasoli, 'Tra Aristotele, Alessandro di Afrodisia e Juan de Valdés'; Del Soldato, Simone Porzio.

16 See Coniglio, Il viceregno di don Pietro di Toledo.

17 See Del Soldato, 'La preghiera di un alessandrista', p. 59.

18 Fornari, Della espositione sopra l'Orlando Furioso, unnumbered pages.

19 De Gaetano, Giambattista Gelli and the Florentine Academy.
} 
and to create a consensus among Florentine élites. In 1541 he appointed a new governing council to the Academy, and changed its name. ${ }^{20}$

Porzio was admitted to the Academy in 1546 , by a unanimous vote, and began to participate in its activities. ${ }^{21}$ In particular, he befriended Giovambattista Gelli, a self-educated tailor proud of his pure Florentine speech: obstinately provincial, he seems to have left his city only once, in order to meet Porzio in Pisa. ${ }^{22}$ Gelli's aim was to confer a new dignity to literary works in the vernacular. In his dialogues I Capricci del bottaio, published in 1546, Gelli insisted on the versatility and excellence of the volgare, capable of expressing any kind of elevated concept. ${ }^{23}$ He had no doubt: if Tuscans made an effort to translate scientific works into their language, in a very short time it would gain greater respect. $^{24}$

In 1539, when Porzio was still in Naples, he published at the Sultzbach press a short Latin treatise which aimed to explain through Aristotelian principles the causes of a terrible earthquake in nearby Pozzuoli. ${ }^{25}$ The treatise received many accolades, and was translated into the vernacular several times - at first on the initiative of individual readers, and then in an official version by the Calabrian monk Ortensio Rizzuto, printed by the same Sultzbach a few months later. ${ }^{26}$ It is unknown what role Porzio had in Rizzuto's translation, nor whether the philosopher himself asked the monk to translate the treatise. But it is on record that he did so with Gelli, asking the tailor to translate his De coloribus oculorum into the vernacular after it was published by the ducal printer Lorenzo Torrentino in $\mathbf{1 5 5}^{\circ}$. Gelli himself recounts the story in his introduction to the translation Sui colori degl'occhi, which appeared few months later: he translated the treatise into volgare following a polite request by Porzio, which Gelli took as an order, such was the admiration he felt for the philosopher. ${ }^{27}$ Porzio was satisfied with Gelli's version and he sent him a letter of praise which was printed with the translation. He ended the epistle by stating:

20 Plaisance, L'accademia e il suo principe, pp. 29-269; Eisenblicher, The Cultural Politics of Duke Cosimo I de'Medici.

21 See Plaisance, L'accademia e il suo principe, p. 227.

22 On Gelli see: De Gaetano, Giambattista Gelli; Perrone Compagni, 'Cose di filosofia si possono dire in volgare'. On his trip to Pisa see Trattatisti del Cinquecento, 1, p. 853.

23 Gelli, I capricci del bottaio, pp. 947-48.

24 Ibidem, p. 965.

25 Porzio, De conflagratione agri puteolani.

26 Rizzuto, Trattato del fuoco apparso in li luochi de Puzolo. The only copy I was able to find is conserved at the Biblioteca Eustachio Rogadeo of Bitonto. See also Del Soldato, Simone Porzio, p. 64.

27 Gelli, Trattato dei colori degli occhi, p. 5 . 
[...] É che e' mi pare che la Filosofia non manco utile a quegli che per ispasso la desiderono intendere, che a quegli che ne fanno professione. [...], per il che come io deggio haver piacere che un tanto mio caro amico sia così nella Filosofia exercitato, così anchora quegli che nell'altra lingua non lo intendevono, ve ne haveranno infinito obligo [...].

It seems to me that philosophy is no less useful for those who wish to grasp it for leisure [«per ispasso»], than for those who practice it for work. $[\ldots]$ Therefore, as much as I have to be pleased that such a dear friend of mine is so well trained in philosophy, those who were not able to understand the work in the Latin version, will be infinitely grateful to you $\left[\ldots .{ }^{28}\right.$

According to Porzio, men who do not know Latin should be grateful to Gelli, who opened to them the benefits of philosophy. What kind of benefits? Porzio's Latin work is primarily described by its own author as a contribution to and an extension of Aristotle and Galen's anatomical studies, with a sort of appendix on physiognomy. Instead, in Gelli's prefatory letter the latter aspect is highlighted: the philosopher has investigated the physical causes of eye-colours and their differences, but in particular he has found the knowledge and clues that can be gained by a physiognomic study, useful for our well-being. ${ }^{29}$ There are no moral implications when Porzio speaks about physiognomy at the end of the De coloribus oculorum, a part elaborated, like the rest of the treatise, according to medical and materialistic criteria. Physiognomy is emphasized in the moral sense, however, in the introduction to the vulgarisation: the technical spirit of the original treatise is shifted to something lighter, which one could have read per ispasso, for leisure. ${ }^{30}$ In the two different versions, Latin and vernacular, the same work would have had different readers, who would have found in it different things, according to their level of philosophical preparation.

A few months later Gelli decided to print another vulgarisation of a short treatise by Porzio, that he had previously completed in order to prepare himself for the translation of De coloribus oculorum. ${ }^{31}$ The book, De puella germanica quae sine cibo potuque biennio vixerat (Sopra quella fanciulla della

\footnotetext{
28 Ibidem, pp. 123-24 (translation is mine).

29 Ibidem, p. 4: 'per giovamento del bene esser nostro'.

30 On the shift in meaning between the original and the popularized versions of a text, cf. the comments in Grendler, 'Francesco Sansovino', p. 142.

31 Gelli, Disputa sopra quella fanciulla della Magna, pp. 3-7. The translation of the De motibus animalium conserved in manuscript at the Biblioteca Nazionale Centrale di Firenze
} 
Magna, in translation), was devoted to the incredible case of a young German girl who lived for two years without eating or drinking around $1542 .{ }^{32}$ This episode attracted interest all over Europe and Porzio had published his work practically simultaneously, while he was still teaching in Naples. He composed this short book in which he explained the event according to Aristotelian humoral theory as an appendix to some university lectures on the second book of the Soul. ${ }^{33}$

Two aspects of Gelli's translation and his decision to publish it are worth noting. First of all he felt the responsibility of bringing the secrets of philosophy into the vernacular ('di mettere i segreti di filosofia in questa nostra lingua'), which highlights the singularity of his effort: in Gelli's opinion, it was impossible to improvise the translation in volgare of subjects that rarely appeared in that language. Secondly, there is the choice of the text, which was not only appropriate for its brevity as training for an aspiring translator of philosophy, but also recounted a mirandum naturae, a genre much loved by readers at court. ${ }^{34}$ To the translation of Porzio's work, which « demonstrated that even if certain events are rare, they don't exceed nature's merit», Gelli appended a short chronicle that supplied the basic facts of Margarete's case. ${ }^{35}$ This addition was useful not only to familiarise readers with an incident that had occurred almost ten years before, but also to offer them in general a concrete and captivating frame which was lacking in Porzio's short treatise, purely concentrated on a technical description of the event. Thus, as in the case of De coloribus oculorum, some precautions were taken in order to make the translation interesting for a larger public.

The next collaboration between the tailor and the philosopher came in a different context: the translation in $155^{1}$ of An homo bonus, vel malus volens fiat (Figs. 5.1 and 5.2). This ethical treatise, in which Porzio affirmed the existence of human free will in a weakened form, had evident theological implications, and although the philosopher confronted the question using an Aristotelian linguistic arsenal, the reading of Erasmus's De libero arbitrio and its Italian

and published in Porcella, 'Giovan Battista Gelli, De' moti o movimenti de gli animali' is probably also related to this training.

32 On Margarete's case see the coeval report by Buchholz, De puella quae sine cibo et potu vitam transigit brevis narratio, also translated in French and German; and Pagano, “ “Admirabilis abstinentia”'; Schutte, Aspiring Saints, pp. 139-42. Porzio, Anima II, ms. A 153 inf., Milano, Biblioteca Ambrosiana, 132v-133r; Idem, De puella germanica quae fere biennium vixerat sine cibo potuque.

34 See Deer Richardson, 'The Generation of Disease'; Siraisi, Medicine and the Italian University, pp. 226-52.

35 Gelli, Sopra quella fanciulla della Magna, pp. 8-14. 


\section{AN HOMO BONVS}

VEL MALVS VOLENS

FIAT, SIMONIS POR-

\section{TII DISPVTATIO,}

Ad Lælium Taurellum iurifconfultifs. Duci Florentinorum à Secretis.

\section{FLORENTI $\mathcal{E}$ XDLI.}

FIgure 5.1 Simone Porzio, An homo bonus, vel malus volens fiat, Florence, 1551. Courtesy of the Kislak Center for Special Collections, Rare Books and Manuscripts, Henry Charles Lea Collection, Van Pelt Library, University of Pennsylvania BJ146o.P67 1551 . 


\section{SE LHVOMO}

DIVENTA BVONO

\section{O CATTIVO VO- LONTARIAMENTE.}

Difputa dello Eccellentifsimo Filofofo M. Simone Portia Napoletano.

\section{Tradotu in volgare per Giowam}

$$
\text { Baiffa Gelli. }
$$

IN FIORENZA.

Appreffo Lorenzo Torrentino.

M D L L.

FIGURE 5.2 Simone Porzio, Se l'huomo diventa buono o cattivo volontariamente, vernacular version, translated by G.B. Gelli. Florence, 1551. Courtesy of the Kislak Center for Special Collections, Rare Books and Manuscripts, Henry Charles Lea Collection, Van Pelt Library, University of Pennsylvania BJ1460.P6. 
reception is evident in the text. ${ }^{36}$ Porzio was involved in the theological (and heterodox) debate of those years, and Gelli was no less interested, in spite of his lack of specific theological training. ${ }^{37}$ Gelli never adhered to a distinct evangelical movement, but he had no problem expressing appreciation for Lutherans and quoting passages from condemned books in his works, ${ }^{38}$ even if his sympathy for evangelical movements had a primarily literary foundation: as he explicitly pointed out, Lutherans were the first to break the monopoly of Latin in biblical study and they made it possible for a wider section of the population to read and interpret the Holy Scriptures. Besides, evangelical propaganda and appreciation of vernacular are often grouped together by scholars, and the case of Gelli and Porzio seems to reinforce this interpretation; if their previous collaborations were simply informed by a linguistic program, in this, and in their subsequent partnerships a common interest in heterodox theology was also present, an aspect which other members of the Accademia Fiorentina would have appreciated: in fact, the conflict which some years prior pitted Cosimo against pope Paul III resulted in the substantial tolerance of the Duke toward unconventional religious behaviour at his court, in particular within the Accademia. ${ }^{39}$

In his preface to the vernacular version of An homo, Se l'huomo diventa buono o cattivo volontariamente, Gelli revealed that he translated Porzio's treatise because he considered the book exceptionally useful and wanted to open it to a larger audience. The volgare can educate people, and Gelli called on the university to legitimize its use. ${ }^{40}$

But if Porzio's Latin version did not hide references the theologians, Gelli tried to censor some of them. Despite following almost literally the topics in Porzio's prefatory epistle in the introduction to his translation, he deleted an allusion to theologians present in the original, doing the same in the final page of the treatise. ${ }^{41}$ Perhaps scared by the first inquisitorial trials in Florence,

36 On Erasmus'presence see Del Soldato, Simone Porzio, pp. 156; 159; 166-69.

37 On Gelli's religion see De Gaetano, Giambattista Gelli, pp. 237-87; Firpo, Gli affreschi di Pontormo a San Lorenzo, pp. 184-91; but also Perrone Compagni, 'Cose di filosofia si possono dire in volgare', pp. 312-37.

38 Gelli, I capricci del bottaio, p. 983 .

39 Firpo, Gli affreschi di Pontormo, pp. 155-217; 313-27; Del Soldato, 'Aristotelici, accademici ed eretici: Simone Porzio e Giovambattista Gelli'. On the relationship between vernacular and religious reformism see in particular Dionisotti, Geografia e storia della letteratura italiana, p. 233 .

40 Gelli, Se l'huomo diventa buono o cattivo, pp. 7-8.

41 Compare Porzio, An homo bonus, pp. 4; 67; Gelli, Se l'huomo diventa buono o cattivo, pp. $6-7 ; 139$. 
which took place precisely in 1551 , Gelli preferred to take some precautions in order to protect a book that contained too many ambiguities. Nevertheless such precautions were strategically located at the beginning and on the last page of the translation: the Christocentrism of Porzio's work, cloaked by paraphrases of the Nicomachean Ethics, was not altered in the rest of Gelli's version.

While in the case of An homo/Se l'huomo, Gelli tried to camouflage the theological matrix, the religious significance is entirely evident in his last translation of Porzio, the commentary on the Pater Noster which appeared in Gelli's vernacular version in ${ }^{1551}$ (Modo di orare christianamente con la espositione del Pater Noster) and only a year later in Porzio's Latin version (Formae orandi christianae enarratio). ${ }^{42}$ Obviously, the fact that the original was published after the translation raises some questions and in the past some scholars proposed to assign to Gelli the real paternity of the work. ${ }^{43}$ However, the discovery of another, prior Latin version of the commentary, undoubtedly demonstrates that Porzio is its genuine author: this earlier treatise, entitled Cristianae [sic] deprecationis interpretatio, was forgotten after being printed anonymously and without any sign of identification in Naples in 1538 (Fig. 5.3). ${ }^{44}$ Porzio's prudence regarding the Interpretatio is easy to explain: the commentary on Pater had become in that period a typical subject of reformed literature-there exist analogous pieces by Luther, Erasmus, and Valdés - and in his own version the philosopher insisted on the sufficiency of the justification sola fide, on a Christocentric vision of the soul's salvation and on a rejection of the idolatry associated with the cult of saints. ${ }^{45}$ It was clear enough that Don Pedro de Toledo would not have appreciated such a book; but the same book was rescued more than ten years later, revised in style and with a completely new meaning, because of a different theological situation. If in 1538 justification was the main issue, in 1551, when the Council of Trent had already settled that controversy, there were other aspects of the commentary that took on relevance: the book's advocacy of an intimate form of prayer, turned inward rather than toward others in the public atmosphere of a church, was becoming in these years the main cliché of Nicodemist literature, which instructed evangelicals

42 Gelli, Modo di orare cristianamente con la espositione del Pater Noster; Porzio, Formae orandi christianae enarratio.

43 For example see Simoncelli, Evangelismo italiano del Cinquecento, p. 365.

44 [Porzio], Cristiane deprecationis interpretatio. See Del Soldato, 'La preghiera di un alessandrista'.

45 See Prosperi, 'Les Commentaires du Pater Noster entre XV et XVI ${ }^{\mathrm{e}}$ siècles'; Idem, 'Preghiere di eretici: Stancaro, Curione e il Pater Noster'. 


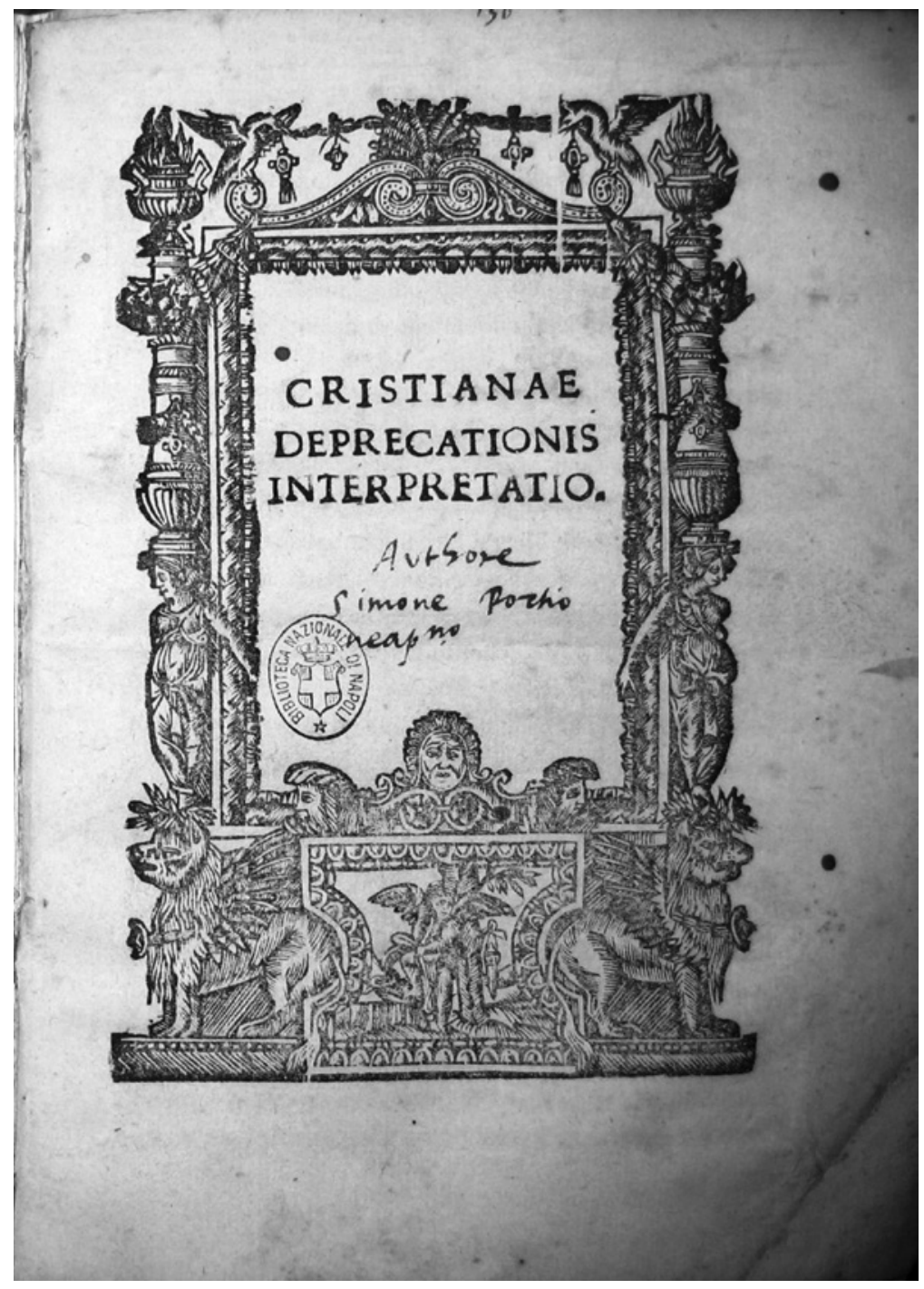

FIG R RE 5.3 Frontispiece of Simone Porzio, Cristianae deprecationis interpretatio, [Naples, 1538]. Biblioteca Nazionale di Napoli S. Q.XXIV G. 34. (reproduction authorized by the Ministero per i Beni e le Attività Culturali; further reproductions are not allowed). 
to publicly follow Catholic orthodoxy in order to hide their unconventional interior adherence to a different faith. ${ }^{46}$

Perhaps aware of this renewed relevance of the work, or perhaps in an attempt to counterbalance the materialistic tone of his former book De mente humana, Porzio asked Gelli to vernacularize the commentary. Gelli, as usual, justifies the translation with his desire to be useful to a large number of people, in consideration of the great importance of the work's subject: being able to pray in the correct way permits men to become friends with God, from whom every good thing comes. ${ }^{47}$ As in the case of the translation of An homo, it was the theological and ethical nature-even leaving aside any heterodox implication - of the work to make it appropriate and worthy of translation. It was not an entertaining work, like De coloribus oculorum and De puella germanica, which had been translated because their themes were attractive to a wide audience, but rather a useful work, which had all the more reason to be welcomed by a significant number of readers.

At the end of 1552, Porzio left Tuscany and returned to Naples in an attempt to recuperate his health on the heights of Posillipo. He died two years later, but his association with Gelli had been already interrupted because of his departure.

We cannot underestimate the importance of the peculiar collaboration between Porzio and Gelli and their instant translations into the vernacular of newly written philosophical works. But at the same time it is important not to forget that - as the tailor expressly affirmed - it was Porzio himself who generally indicated to him which books to translate and that the most theoretical and important treatises of the philosopher were not included in this project. The De coloribus (1548) - a philological commentary in which Porzio attributed to Theophrastus a work on colours traditionally believed to be Aristotelian-, the medical treatise De dolore (1551), the De mente humana (1551) - an original exegesis of Aristotle's De anima - and the De rerum naturalium principiis (1553, but finished one year before) - a commentary on the second book of Physics - were not translated by Gelli, at least in print: in fact there does exist in Paris a manuscript translation of the De mente humana, which nonetheless cannot be attributed to him with any certainty. ${ }^{48}$

46 On Nicodemism see: Ginzburg, Il Nicodemismo; Biondi, 'La giustificazione della simulazione nel Cinquecento'; Eire, 'Calvin and Nicodemism: a Reappraisal'.

47 Gelli, Modo di orare, p. 7.

48 Ms. Par. Ital. 441, Paris, Bibliothéque Nationale de France; on the manuscript see Montù, 'La traduzione del “De mente humana” '; De Gaetano, Giovanbattista Gelli, pp. 56-65; Del Soldato, Simone Porzio, pp. 124-26. 
Thus, if it is clear which works were vernacularised by Gelli under Porzio's direction, and why, it remains to be explained why he did not receive the same assignment for these other books.

The answer lies in the strictly technical subjects of these treatises, accessible only to a narrow circle of professional doctors or philosophers who were unquestionably skilled in Latin, the language of the universities where they worked. Gelli's translation opened a selected list of Porzio's writings to the court or bourgeois readers, who might be interested in physiognomy, miranda naturae or ethical-theological issues, but not at all in abstract dissertations about matter and first causes, which would have in any case required a hightoo high-level of philosophical preparation both for the translator and the reader. This distinction is also evident in the catalogue of Lorenzo Torrentino, the printer of the Accademia Fiorentina, where the section devoted to philosophy in vernacular consists only of ethical or aesthetic works, while the Latin dominion of professional philosophy was still larger and more complex:49 Porzio was aware of this and he took care to separate these two levels in his vernacularisation program, which was limited to ethics or to simplified applications of philosophia naturalis. And, on the other hand, the different nature of these parallel editions of Porzio's philosophical works in Latin and in the vernacular is reflected in their respective formats: a solemn $4^{\circ}$ format for the professional Latin versions, a practical $8^{\circ}$ for their vernacular counterparts. ${ }^{50}$

There is a furher confirmation of Porzio's ambiguous attitude towards the vernacular: we know that he composed at least six short treatises in volgare on his own, none of which was ever printed. ${ }^{51}$ They are almost all love treatises and this explains the language in which he chose to write them: they belong to a tradition well embedded in academies and courts, but substantially foreign to the university. It is not a coincidence that Porzio began the composition of

49 Moreni, Annali della tipografia di Lorenzo Torrentino; see also Bionda, 'Aristotele in Accademia'; Brancato, 'Benedetto Varchi traduttore di Boezio'.

5o On the meaning of these features see the works by Chartier, but in particular The Order of Books.

51 Ms. Brancacciano V D 17, Napoli, Biblioteca Nazionale, $1 r-71 r$; Mss. Ashburnham 436, $17 r-31 v ; 674,67 v-90 r$, Firenze, Biblioteca Laurenziana. Apart from the Florentine version of the Trattato d'amore (Ashb. 674), edited by Benvenuti ('Simone Porzio e il "Trattato d'amore" '), the other works are published in Del Soldato, Simone Porzio, pp. 199-244. Another vernacular short piece by Porzio, the De sensi or Del sentire, is conserved in two different versions in Naples (Mss. Brancacciano V D 13, 101r-107r; V D 17, 16 $5^{r-174 v}$ ). This is a popularization - probably addressed to a courtier audience - of Simplicius' exegesis of Aristotle. It is published in Castelli, 'Il “De' sensi” e il "Del sentire" di Simone Porzio'; and in Del Soldato, Simone Porzio, pp. 245-55. 
his principal love treatise at a court, that of Salerno, around 1535, finishing it only twenty years later for Duke Cosimo. ${ }^{52} \mathrm{He}$ evidently did not feel a particular interest for the subject, which wove Aristotelian doctrines together with a comment on Petrarch. The philosopher himself presented his work as literally an 'abortion', as a bagatelle, because he was aware of the modest theoretical importance of its subject. ${ }^{53}$ In short, all of Porzio's vernacular work was tied to the context of the court, which determined both the subject and the language in which it was written, and the philosopher, by his own admission, did not regard these pieces as serious contributions.

Magister Porzio, even while participating actively in the world of the linguistic academies, still maintained some prejudices towards the philosophical use of the vernacular. He spoke Latin in the university and in his technical works, as a professor, and he spoke volgare — and let his works do the same-at court, where he was free to offer translations of his most accessible treatises to the academics. Porzio did not challenge the tradition, but, to paraphrase Speroni's Pomponazzi, he nevertheless helped to make his age speak and write in volgare, though not only about vulgar and poor subjects.

52 Porzio, Trattato d'amore, ms. Ashb. 674, $67 v$.

53 Ibidem: 'tanto bassa la materia sua.' 